\title{
Estimation of insurance-related losses resulting from coastal flooding in France
}

\author{
J. P. Naulin ${ }^{1}$, D. Moncoulon ${ }^{1}$, S. Le Roy ${ }^{2}$, R. Pedreros ${ }^{2}$, D. Idier ${ }^{2}$, and C. Oliveros ${ }^{2}$ \\ ${ }^{1}$ CCR, 157 bd. Haussmann, 75008 Paris, France \\ ${ }^{2}$ BRGM, 3 av. C. Guillemin, 45060 Orléans, France \\ Correspondence to: D. Moncoulon (dmoncoulon@ccr.fr)
}

Received: 24 March 2015 - Published in Nat. Hazards Earth Syst. Sci. Discuss.: 24 April 2015

Accepted: 30 December 2015 - Published: 20 January 2016

\begin{abstract}
A model has been developed in order to estimate insurance-related losses caused by coastal flooding in France. The deterministic part of the model aims at identifying the potentially flood-impacted sectors and the subsequent insured losses a few days after the occurrence of a storm surge event on any part of the French coast. This deterministic component is a combination of three models: a hazard model, a vulnerability model, and a damage model. The first model uses the PREVIMER system to estimate the water level resulting from the simultaneous occurrence of a high tide and a surge caused by a meteorological event along the coast. A storage-cell flood model propagates these water levels over the land and thus determines the probable inundated areas. The vulnerability model, for its part, is derived from the insurance schedules and claims database, combining information such as risk type, class of business, and insured values. The outcome of the vulnerability and hazard models are then combined with the damage model to estimate the event damage and potential insured losses. This system shows satisfactory results in the estimation of the magnitude of the known losses related to the flood caused by the Xynthia storm. However, it also appears very sensitive to the water height estimated during the flood period, conditioned by the junction between seawater levels and coastal topography, the accuracy for which is still limited by the amount of information in the system.
\end{abstract}

\section{Introduction}

The Xynthia storm, which occurred in France in February 2010, renewed the awareness of coastal flooding risk on the French coast (Lumbroso and Vinet, 2011). This peril, resulting from the combination of high spring tide and severe meteorological conditions (maximum instant wind comprised between 100 and $140 \mathrm{~km} \mathrm{~h}^{-1}$ in the most affected areas), led to very high levels of loss; both in term of death and injury and in resultant economic losses. The financial cost of Xynthia has been estimated to have been approximately EUR 2.5 billion, of which EUR 1.5 billion was covered by insurance and reinsurance companies (FFSA and GEMA, 2011). In terms of insurance payments, Xynthia is one of the most costly storm events to have occurred in France in the last 30 years.

In France, the financial compensation for the victims of such natural disasters is governed by the national Natural Catastrophes system (hereafter the NatCat system). This has provided approximately EUR 713 million for the victims of Xynthia. This system engages CCR (Caisse Centrale de Réassurance), a reinsurance company which is owned by the French state, to administer the state guaranty for NatCat events.

In order to meet the needs of the French state and its clients, and for its own income forecasts, CCR has developed models aiming to estimate the insured losses arising out of NatCat events (floods, coastal flooding, windstorms, droughts, earthquakes, and volcanic eruptions). The strategy of CCR is to develop its own modelling tools for natural disasters in order to have control over the different components of the model and to validate them with the available data. The 
development of such models is also made possible by the significant database of insurance schedules and claims that have been collated by CCR with the support of its "cedants" (cedant - this term designates the client companies of CCR).

Coastal flooding modelling faces several issues: scales (multi-frequency and multi-spatial-scale processes), process interaction related to the forcing conditions (waves, surge, tide, river discharge etc.), coastal flooding process complexity (overtopping, interaction with structures, etc.), and a detailed enough knowledge of the topography and associated structures. Several approaches have been developed to estimate coastal flooding, ranging from the simple approach of estimating flooding from topographic contours to the more accurate 2D/3D, time-varying, full-process models. Estimating flooding from topographic contours leads to an overestimation of the flood event, without providing any information on the velocity or the temporal dynamics (e.g. Breilh et al., 2013).

Recent modelling developments now permit realistic 2D simulations of urban areas conditions (Le Roy et al., 2015) but still with computation time exceeding several days to simulate a few event hours. Some regional models such as the ones developed over the last 5 years in the United States (Bunya et al., 2010) have demonstrated that it is possible to simulate coastal flooding at a regional scale. These models could be an interesting alternative for operational purposes, but they require massively parallel computational methods.

To tackle the issue of estimating coastal flooding on a national scale, a compromise has to be found between the quality of the results, feasibility (data available), and computational time. This leads to the necessity of developing alternative approaches, between those of basic static projection of water levels and the most advanced approaches used for projecting events in urban areas.

The requirements of CCR correspond to two objectives. The first is to determine the likely affected areas and the resultant cost of catastrophic events a few days after their occurrence. This estimation allows CCR to advise the French state and its clients of the potential financial magnitude of the event. The second objective is to assess the potential losses due to extreme events according to their return period. Successful achievement of this objective will allow effective evaluation of the financial exposure of CCR, the French state, and of cedants to coastal flooding risk.

In order to fulfil the first objective for storm surge projection, a deterministic model is currently being developed by CCR. Numerous studies have been published on the estimation of flood damages (Jongman et al., 2012; Meyer et al., 2013; Meyer and Messner, 2005). Generally, these models combine a hazard model, which characterizes the intensity of the event, a susceptibility model, which describes the exposure of the subject area, and a damage model, which estimates the financial cost. In the same way, some specific models have been developed for storm surge, especially for tropical cyclones in America (Genovese et al., 2011; Wang et al., 2014) or in the Netherlands - dealing with the problematic nature of polder areas (de Moel et al., 2012; Bouwer et al., 2009). These models are most often concerned with the global economic cost, but some more specific works have concentrated on the insurance cost. For example, Pistrika and Jonkman (2009) have studied the insurance cost due to hurricane Katrina. Sousounis and Kafali (2010) have used the AIR model in a recent study to estimate the potential cost of the 1959 typhoon in Japan. Some models use a probabilistic approach, like Gaslikova et al. (2011), for the consideration of future storm surge impact in the North Sea region. The approach of Czajkowski et al. (2013) presents a methodology to determine premiums on the basis of property exposure to coastal flood risk.

For CCR, the loss consideration will not concern itself with damage to public infrastructure, assets, or agricultural losses, as these are not included in the NatCat compensation system. Thus, a specific calibration is needed such as it has already been established for inundation by CCR (Moncoulon et al., 2014).

In order to estimate the losses related to coastal flooding events, the deterministic model has been developed with the same structure used in most of the insurance-related catastrophe models: a hazard model, a vulnerability model, and a damage (financial loss) model. This development should face two main challenges. The first one is the operational modelling of the inundation that results from coastal flooding hazard at a large scale (the French coasts) and within a short time frame, and the second consideration integrates the hydrodynamics' output and the limitations of the insurancerelated data.

The present paper examines the methodology developed for a timely estimation of the costs generated by coastal flooding: a hazard model is used to estimate flooded areas, and a vulnerability model then allows estimation of the exposure of insurance policies to coastal flooding, before finally calculating the potential cost of the event through a damage model. This methodology has been applied to the data relating to the major coastal flooding that occurred during Xynthia storm in France in 2010. A sensitivity analysis has permitted a full understanding of the effectiveness of the hazard model in interpreting/predicting the results, and permitted the application of the methodology to four other minor events, showing the consistency of the results.

\section{Hazard model}

\subsection{Methodology}

The purpose of the hazard model is to estimate the water levels over the land areas where there is likely to be insurance policy coverage. During a storm event, water levels along the coastline are influenced by three main processes. The first one is that of tide variation, which plays an im- 
portant role along the Atlantic coast of France, the Channel, and the North Sea. The amplitude can vary from 3 to $11 \mathrm{~m}$ for spring tides (SHOM, 2012). The second process is atmospheric storm surge, resulting essentially from atmospheric pressure and wind effects, and its coincidence with high tides. For Xynthia, this surge was estimated to have been $1.5 \mathrm{~m}$ at La Rochelle (Bertin et al., 2012).

In this study, we chose to use the PREVIMER system (www.previmer.org) to determine potential water levels resulting from these two processes. This system provides both forecasts and observations of water levels, but also models waves, currents, temperatures, and plankton content.

The third component is the wave set-up which corresponds to the surge that is generated by the wave breaking over the beach. This surge component, not provided within the PREVIMER model, could represent a significant part of the total surge effect (Holman and Sallenger, 1985) and is estimated on the basis of the wave characteristics.

Once the total water levels have been estimated along the coastline, an inundation model propagates them over the landmass behind. For this purpose, an inundation model, similar to the LISFLOOD-FP model (Bates et al., 2010), is utilized.

Finally, this modelling chain allows estimation of the inundation process by assessing the volume of the overflowing seawater, but this is projected without the additional consideration of the consequences of wave overtopping or the destruction of sea defenses.

\subsubsection{Tide, atmospheric storm surge, and regional wave set-up}

The PREVIMER system, created in 2006 (Muller et al., 2014), uses the MARS-2D hydrodynamic model (Lazure and Dumas, 2008), and usually shows satisfactory results (Idier et al., 2012). The model is based on the resolution of shallowwater equations with the finite difference method. The model runs on three different levels of resolution: $2 \mathrm{~km}$ for the north-east part of the Atlantic Ocean, $700 \mathrm{~m}$ for the Channel and the Bay of Biscay, and $250 \mathrm{~m}$ for five smaller areas. The bathymetry used by PREVIMER is based on the NOOS $1^{\circ}$ (North-West Shelf Operational Oceanographic System), EMODNET (European Marine Observation and Data Network), and the SHOM-Ifremer digital terrain model (DTM) at 100 and $500 \mathrm{~m}$ resolution. The MARS-2D model uses the FES2004 tide model (Lyard et al., 2006) for the two lowest resolutions and the model cstFrance (Simon et al., 2011) with 115 harmonic constants at $250 \mathrm{~m}$. The meteorological data are provided by Meteo France and are based on Arpege (Courtier et al., 1994) and Arome models (Seity et al., 2011) whose resolutions are, respectively, 0.5 and $0.025^{\circ}$.

The validation of the model, presented in Muller et al. (2014), has shown that root-mean-square errors (RMSEs), calculated on the basis of hourly data, are usually comprised between 5 and $14 \mathrm{~cm}$, with a mean of $9 \mathrm{~cm}$, which is deemed to be satisfactory. However, these errors can be higher for exceptional events such as Xynthia. The difficulties of generating an effective estimation of the water levels for Xynthia could be explained by the fact that this event had characteristics which were quite unusual. Indeed, Bertin et al. (2012) have shown that the associated surge was exceptionally high for this event in comparison to the intensity of the storm. This behaviour could be explained by the trajectory of the depression that induced Ekman transport directed toward the coast, enhanced by the presence of young and steep waves (Bertin et al., 2014).

The version of PREVIMER used in this study tends to underestimate water levels observed in the central part of the Bay of Biscay during the Xynthia event. According to the tide gauge measurements, this underestimation could reach 30 to $40 \mathrm{~cm}$ in some sectors. In order to use the PREVIMER outputs in the best conditions for our system, the simulated water levels have been adjusted to match the highest levels observed by tide stations during the simulated events. To realize this correction, an adjustment value is computed for each pixel located along the coast on the basis of a linear regression between the errors that are measured for the two nearest stations. It should be noted that tide gauge measurements include tide and atmospheric storm surge, but also regional wave set-ups. Indeed, for instance, as shown by Bertin et al. (2015), the total water level result from these processes with a regional wave set-up was between 5 and $10 \mathrm{~cm}$ at La Rochelle. Thus, our calibration method indirectly permits the taking into account not only of tide and atmospheric surge, but also of the regional wave set-up. An illustration of two mareographs obtained for Xynthia is presented in Fig. 1 and shows that RMSEs were generally between 10 and $30 \mathrm{~cm}$ for this event.

\subsubsection{Wave set-up}

Waves could also play a key role in the inundation processes during storm surges with the phenomena of wave setup and wave run-up (Kim et al., 2008; Ferrarin et al., 2013). However, it is relatively difficult to estimate these parameters accurately, especially on a large scale and with poor bathymetry. In addition, as discussed in the water level calibration step, two kinds of wave set-up can be identified: regional wave set-up, occurring over large areas such as bays (see e.g. Bertin et al., 2015) - which can be reproduced utilizing a rather coarse grid (e.g. $50 \mathrm{~m}$ grid size); and local wave set-up, resulting from localized waves breaking near the coast, usually requiring finer grids ( $5-10 \mathrm{~m}$ grid size). As discussed in the above, the regional set-up, even if not actually calculated here, has been indirectly integrated into the adjustment of the simulated water levels against the actual water levels observed by the tide stations which are included in this regional set-up model. Thus the values of the local wave set-up, given as $\eta$, are estimated within the empirical formula of Stockdon et al. (2006): 

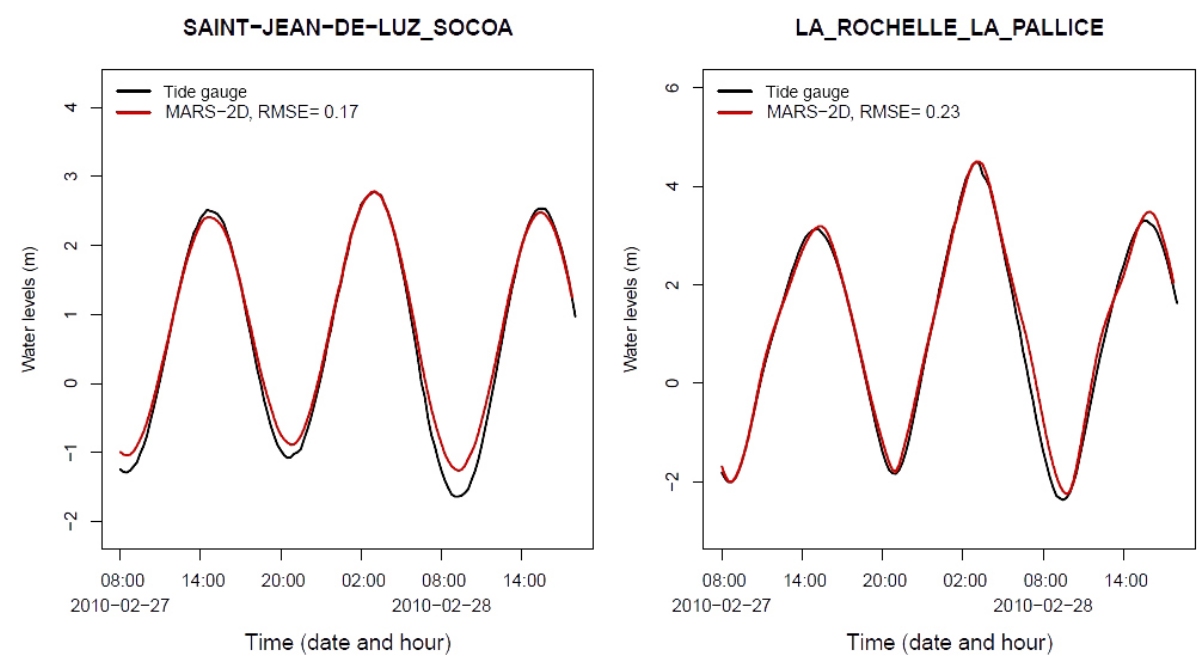

Figure 1. Comparison between the observed tides and the water levels estimated by the PREVIMER for the Xynthia event at two gauge stations after maximal water levels adjustment.

$\langle\eta\rangle=0.35 \beta_{f}\left(H_{0} L_{0}\right)^{1 / 2}$.

The parameters of this formula (deep water wavelength, $L_{0}$; the significant wave height, $H_{0}$ ), are computed using PREVIMER wave data (Ardhuin et al., 2010). The third parameter, representing the beach steepness, $\beta_{f}$, was estimated on the basis of the BD CARTO (IGN database). This database contains the limits of the low and high spring tide. The distance and the height between them are used to roughly estimate the beach slope. In order to measure and compare offshore parameters and those for beaches, vectors for the coastline were established every $250 \mathrm{~m}$ and a cross section was established to determine the coordinates of the parameters. A selection of these cross sections were then scrutinized; the sections for which the bathymetry did not reach a $20 \mathrm{~m}$ depth within a $5 \mathrm{~km}$ range offshore were deleted from the wave setup computation. In the same way, in harbours, the cross sections have been deleted and instead the statistical set-up of the surrounding beaches is applied.

Figure 2 shows the maximal wave set-up height computed for the Xynthia event along the coast. The mean height often reaches $40 \mathrm{~cm}$ but extends to $80 \mathrm{~cm}$ for the most exposed areas. This empirical estimation of the local wave set-up provides results of the same order as those obtained by Bertin et al. (2015) by coupling a spectral wave model (WWM) and the SELFE hydrodynamic model (local wave set-up can locally exceed $0.4 \mathrm{~m}$, even if the calculation resolution remains too coarse to capture the maximum set-up along the coastline). These values justified the necessity of taking this phenomenon into account. However, the methodology presents two main limitations. In effect, the WWIII model used by PREVIMER simulates the refraction phenomenon but the spatial resolution does not always permit an accurate representation of local refraction at the coast. For the moment, the

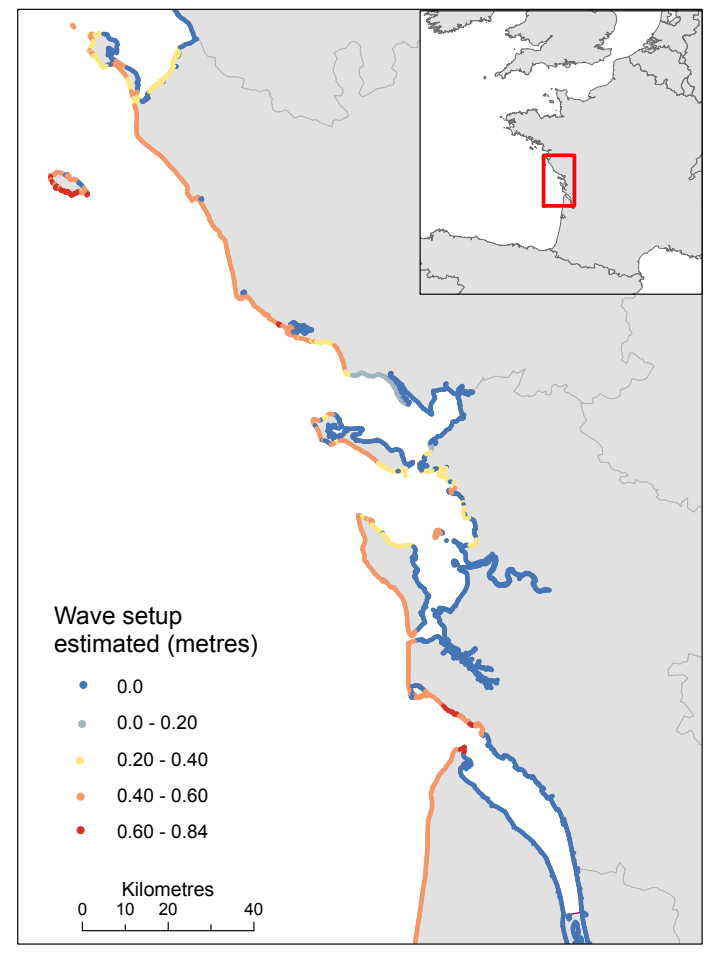

Figure 2. Maximal estimated local wave set-up, computed according to Stockdon et al. (2006) along the coastline for the Xynthia event.

actual model does not take the reverse shoaling effects into account. It could be interesting, in the future, to use the correction of $H_{0}$ proposed in Lecacheux et al. (2012) in order to reflect the conditions of the Stockdon et al. (2006) formula (deep water and waves perpendicular to the coast). The second limitation is that local wave set-up, which could im- 
pact sheltered bays, is not considered. However, as explained above, the regional wave set-up is indirectly taken into account, such that the wave set-up along sheltered bays is not nullified. The potential impact of these limitations will be discussed in Sect. 4.3.

\subsubsection{Coastal flooding model}

Water levels estimated along the coastline are then propagated onto the land using an inundation model. Given the large scale and the operational aspects of the study, an application of full-process based model (for example based on non-linear shallow water equations or on Boussinesq equations) would have been too cumbersome to implement given the need for extensive spatial information and significant computational times required. As a result, a storagecell flooding model has instead been used, similar to the LISFLOOD-FP model (Horritt and Bates, 2001; Hunter et al., 2005; Bates et al., 2010) that has been tested for the computation of coastal flooding by Bates et al. (2005) with good results. The model developed in this study is based on the continuity equation relating to flow and volume changes:

$\frac{\partial h^{i, j}}{\partial t}=\frac{Q_{x}^{i-1, j}-Q_{x}^{i, j}+Q_{y}^{i, j-1}-Q_{y}^{i, j}}{\Delta x \Delta y}$

where $Q^{i, j}$ represents the flows $\left(\mathrm{m}^{3} \mathrm{~s}^{-1}\right)$ between cells at the node $(i, j), x$ stands for horizontal and $y$ for vertical flows, $\Delta x$ and $\Delta y$ are the cell dimensions (m), $h$ is the free water surface and $t$ is the time (s). The flows between cells are estimated according to Manning Striker law with, for example in the $x$ direction:

$Q_{x}^{i, j}=\frac{1}{n}\left(h_{\mathrm{fmax}}-z_{\max }\right)^{5 / 3}\left(\frac{h^{i-1, j}-h^{i, j}}{\Delta x}\right)^{1 / 2} \Delta y$,

where $n$ is the Manning's friction coefficient, $h_{\text {fmax }}$ the highest water free surface in the two cells, and $z_{\max }$ the higher bed elevation.

The digital terrain model (DTM) used for this study is a commercial DTM that presents a spatial resolution of $25 \mathrm{~m}$. This product could be considered has a temporal solution since a lidar-based DTM called Litto 3D is developed over the French territory. This DTM that would present a $1 \mathrm{~m}$ spatial resolution is currently freely available in different sectors such as Brittany or Mediterranean areas. However, according to the application scale of this study, it seems preferable to use a homogeneous DTM, available all over the coastline. In order to apply the model within operational perspectives, the French coast has been divided into 39 sectors, exempted from interdependency, where the model is applied independently.

In order to take into account the roughness of the ground, the Manning's coefficient $(n)$ is fixed according to the land use described in the Corine Land Cover database (2006), using the coefficients proposed by Lopes et al. (2013) for the Ria de Aveio at Portugal.

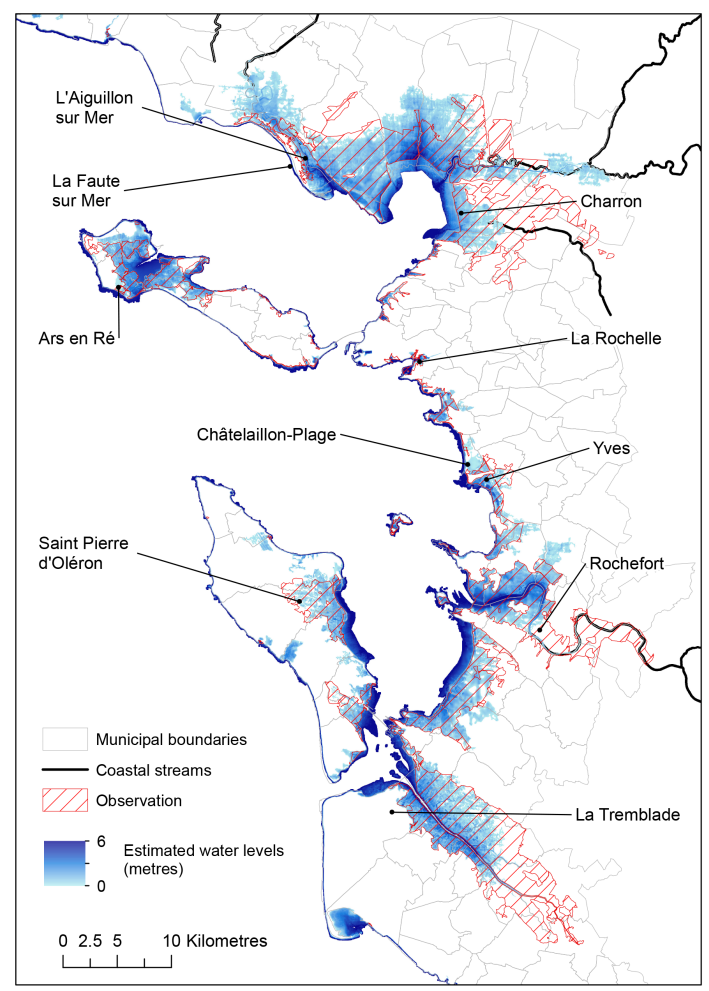

Figure 3. Simulated and observed inundated areas for the Charente Maritime County for the Xynthia event.

Finally, the modelling process permits a chronological estimation of water levels for each cell of the DTM. Accordingly it is possible to extract, for each cell, the highest free surface water height presented by the damage model. This storage-cell model presents the dual advantages of being easy to set up and having a relatively fast computational time.

\subsection{Results}

After the Xynthia storm, inventories of inundated areas were collated. These inventories have been used in our study to compare the simulated flood areas and the observed inundated areas. The results of this comparison, presented for the Charente Maritime department in Fig. 3, show that the hazard model allows a good global representation of the inundated areas with significant differences at the local scale: the CCR model makes projections of an inundated area of $670 \mathrm{~km}^{2}$ against $595 \mathrm{~km}^{2}$ that was actually affected.

The fraction $F$ of the domain classified correctly by the model was calculated on the basis of the formulae proposed by Aronica et al. (2002):

$F=\frac{\sum_{i=1}^{n} P_{i}^{D_{0} M_{0}}+\sum_{i=1}^{n} P_{i}^{D_{1} M_{1}}}{n}$,

where $n$ is the number of pixels in the domain, $P_{i}^{D_{0} M_{0}}$ the pixels not inundated in reality and not detected by the model, 
and $P_{i}^{D_{1} M_{1}}$ the pixels inundated and detected by the model. The fraction obtained is $85 \%$ for the considered domain which represents $4363 \mathrm{~km}^{2}$. This result confirms a satisfying behaviour of the model at a global scale with, however, notable differences at a local scale.

The cartography presented in Fig. 3 highlights areas where the extent of the inundation is widely underestimated. This is the case, for example, for the municipalities of Charron or Saint Pierre d'Oléron. These deviations could be due to an underestimation of seawater levels in sheltered bays, but perhaps mainly by the quality of the DTM used. Indeed, at $25 \mathrm{~m}$ of resolution, dikes and protection walls have been smoothed, despite some corrections, and this could skew the real water level estimation. The quality of the DTM will be discussed in Sect. 3.2. In such flatlands, a few centimetres' difference in water levels induces very different estimations of the inundated areas (see Sect. 4.3).

There are contrary cases where the model seems to overestimate flooded areas as, for example, on the Île de Ré or Île de Noirmoutier. The consequences are opposite, but the origins of the problem could be the same: the approximate estimation of water levels in the sea and the quality of the DTM used.

The one-way nesting approach that has been developed in this study could also be limited by the problem of the limitation of water levels during flooding. Indeed, several studies showed that the consideration of the hydrodynamic model boundaries as impenetrable barriers could cause water level overestimations, given the fact that water could not flood the lands (Towned and Pethick, 2002; Bertin et al., 2014). The analysis of this phenomenon realized by Waeles et al. (2014) for Xynthia shows that this phenomenon could be very significant in the case of enclosed bays and estuaries where the overestimation may exceed $0.5 \mathrm{~m}$.

However, in our case, it is difficult to evaluate the divergence given the fact that the spatial resolution of PREVIMER is lower than the one used by Waeles et al. (2014) and may underestimate water levels locally. The adjustment of simulations realized on the basis of tide measurements could also partially compensate the overestimation induced by the limitation of water levels.

Lastly, it appears also that the quality of the meteorological data used by PREVIMER in 2010 was limited; there is a resolution of $0.5^{\circ}$ and a time step of $6 \mathrm{~h}$ (Arpege model). Since 2012, the PREVIMER system has used Arome meteorological data with hourly time steps and a spatial resolution of $0.1^{\circ}$. This difference of the qualitative information explains why PREVIMER outputs underestimate water levels for the Xynthia event, in particular for bays such as the Aiguillon Bay, where a simulation realized with Arome data indicates that water levels could be underestimated by about $40 \mathrm{~cm}$.

It is possible that the water level limitation effects are compensated by these two aspects and that finally, water levels are underestimated given the low inundation spread observed in the Charron sector.
The results also illustrate an incorrect reproduction of the behaviour of inundation processes along the coastal inlets and estuaries. This is noticeable for the municipality of Rochefort, for example where the inundation has been induced by the interaction between the river flow and the sea. This problem has not yet been fully remedied in the actual version of the inundation model, but when this happens, this should probably improve the results substantially. Apart from in these areas, the simulations are in reasonable agreement with the floods observed.

\section{Vulnerability model and hazard validation}

\subsection{Vulnerability database}

The vulnerability model developed by CCR is derived from schedule information and loss records, termed henceforth "insurance policies". A database was created under the framework of bilateral contracts with insurance companies under conditions of confidentiality. The fact that CCR provides cover for a very large proportion of individual French insurance policies offers a particularly broad vision of French exposure to coastal flooding risks.

This database describes the nature of the risk (house, building, or apartment), its usage (residential or commercial), and its occupation (owner, tenant, co-ownership). For a large part of them, these risks have been geo-referenced. The latitude and the longitude are estimated on the basis of the location of the address in the street and not the real location of the building. Its real position could vary from a few metres to several thousand in some cases. In some cases, data sources do not permit a specific designation of the property locus, and the co-ordinate of the nearest street or commune centre has therefore been adopted. Some complementary elements have been extracted from a DTM such as the distance to the coastline or the location elevation.

Additionally, when companies renew their contracts, they transmit details of historic claims. It is thus possible to associate each claim with an historic flood loss event and so to estimate the global insured cost of each past event that is managed under the NatCat system. For the coastal flooding risk evaluation, the historic claims have been consolidated for three events for the studied area: Lothar and Martin (1999), Johanna (2008), and Xynthia (2010).

\subsection{Hazard validation}

The claims' localization could be considered a spatial indicator of the extent of the flood. Initial geographic comparisons between observed and simulated inundated areas and claims were evaluated. These comparisons are shown in Fig. 4 for the commune of Châtelaillon-Plage locally. This example shows first that the claims data have not always been effectively localized, as examination of the detail shows that the claims clustered in the town centre. Indeed, the delineation 


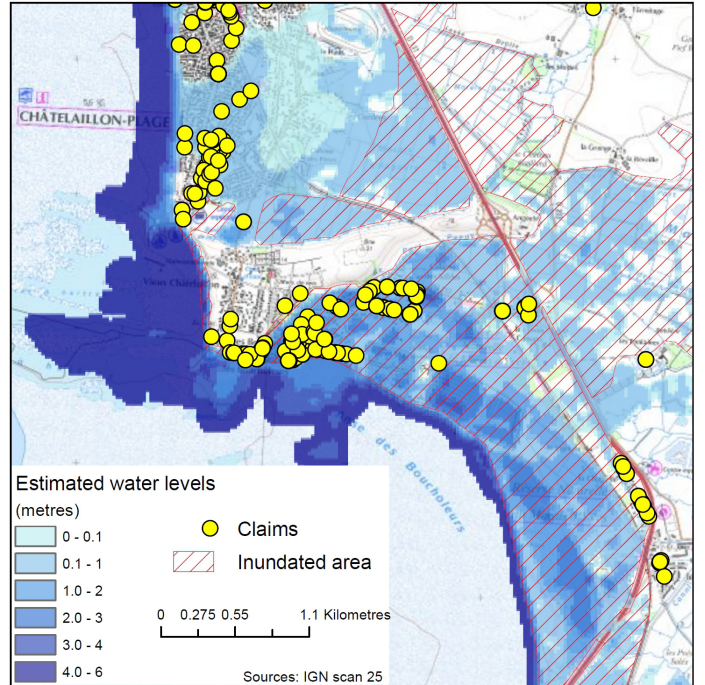

Figure 4. Claims and inundated areas for the Châtelaillon-Plage municipality during Xynthia.

of inundated areas, often produced a few days after an event on the basis of satellite data, could show that claims data input, where not sited in the actual location of the flood event, could miss some important areas, especially in the marsh areas. Furthermore, these data inventories could miss sectors where flood water has just run off and not remained as standing water to be recorded after the initial flood event.

This figure also shows some isolated claims not explained by overflowing simulation alone. This is the case for claims localized into the Vieux-Châtelaillon sector, where the elevation of the DTM is relatively important. Often, these problems are explained by the localization of the insurance policy details, but they could also result from local conditions such as streams or urban water network overflowing (as opposed to actual coastal inundation) and cellar inundations.

Two indicators (Wilks, 2011) have been computed to evaluate hazard model performances on the basis of their ability to detect claims.

- The probability of detection (POD) is the ratio of the claims detected by the model to all of the actual claims. The POD evaluates the capacity of the model to detect claims, the best case being a POD of $100 \%$.

- The probability of false detection (POFD) is the ratio of false alarms (policies detected wrongly by the model as being flooded) to the number of policies that have not been the object of a claim. A POFD of $0 \%$ would be ideal.

Both indicators have been calculated for Xynthia at two scales: the national and the communal scale. At the national scale, the results give a POD of $58 \%$ for a POFD of $4 \%$, which means that the system missed a significant number of claims (42\%) and selected a non-negligible number of policies that have not been affected. However, the comparison of these policies with areas identified as flood-affected allows us to put our scores into perspective, as actual inundated areas only enabled us to detect $72 \%$ of claims and also generated false claim reports $(\mathrm{POFD}=1.2 \%)$.

The results obtained at the communal scale, presented in Fig. 5, also give additional information. Firstly, they appear strongly correlated with the results of the hazard model presented previously. Thus, municipalities with high POD and low POFD are generally well simulated in terms of hazard. In the same way, when both POD and POFD are low, the extent of the inundation is generally underestimated. This is the case for the municipalities of La Flotte and Charron that should normally appear as some of the most affected areas. It also appears that hazard is sometimes overestimated when both POD and POFD are high, notably in the western part of the Île de Ré or in the sector of Noirmoutier.

The major limit of the hazard model is the quality of topographic data. This is particularly visible in Fig. 6 that shows a comparison between the DTM used in this study and the terrestrial part of the Litto 3D DTM (RGE ALTI ${ }^{\circledR}$ IGN) for the same cross section located in the commune of Yves (lower part of Fig. 3). The RGE ALTI DTM has been interpolated with a $25 \mathrm{~m}$ resolution with respect to coastal protections levels. The differences between the two DTMs seem very significant with an average value of $1 \mathrm{~m}$ and up to $2 \mathrm{~m}$ at the location of the dike whose width, narrower than the $25 \mathrm{~m}$ resolution, does not allow it to be well represented in the DTM used. The analysis of this DTM shows two shortcomings. The first is that it generally underestimates the elevation of coastal protection, especially when it is narrower than the DTM resolution, and the second is that it seems generally "smoothed" in the urban area where it overestimates the elevation of the ground. However, it has the advantage of being more accurate than the ASTER GDEM (Rexer and Hirt, 2014) and of being available all over French territory, while the Litto 3D DTM is not yet implemented throughout French territory. Furthermore, the implementation of hydraulic connections such as conduits or bridges also needs to be addressed with a good-quality DTM.

The vulnerability model could also explain the scores obtained. The first limit is that the data inventory is not always exhaustive. Indeed, when losses are lower than the amount of the insurance franchise (deductible), claims are generally not declared. This situation could explain the high number of false alarms computed. The second limit comes from the localization of the policies. As indicated in Sect. 3.1, this loss localization is deduced from the address transmitted by the cedant. A comparison with the real locus of the policy (and therefore of the loss) has shown that about $30 \%$ of policies are, in reality, located at a distance greater than $50 \mathrm{~m}$ from the estimated coordinates. The third limit of the vulnerability model is that it often does not distinguish secondary residences from main residences. This could generate a signifi- 


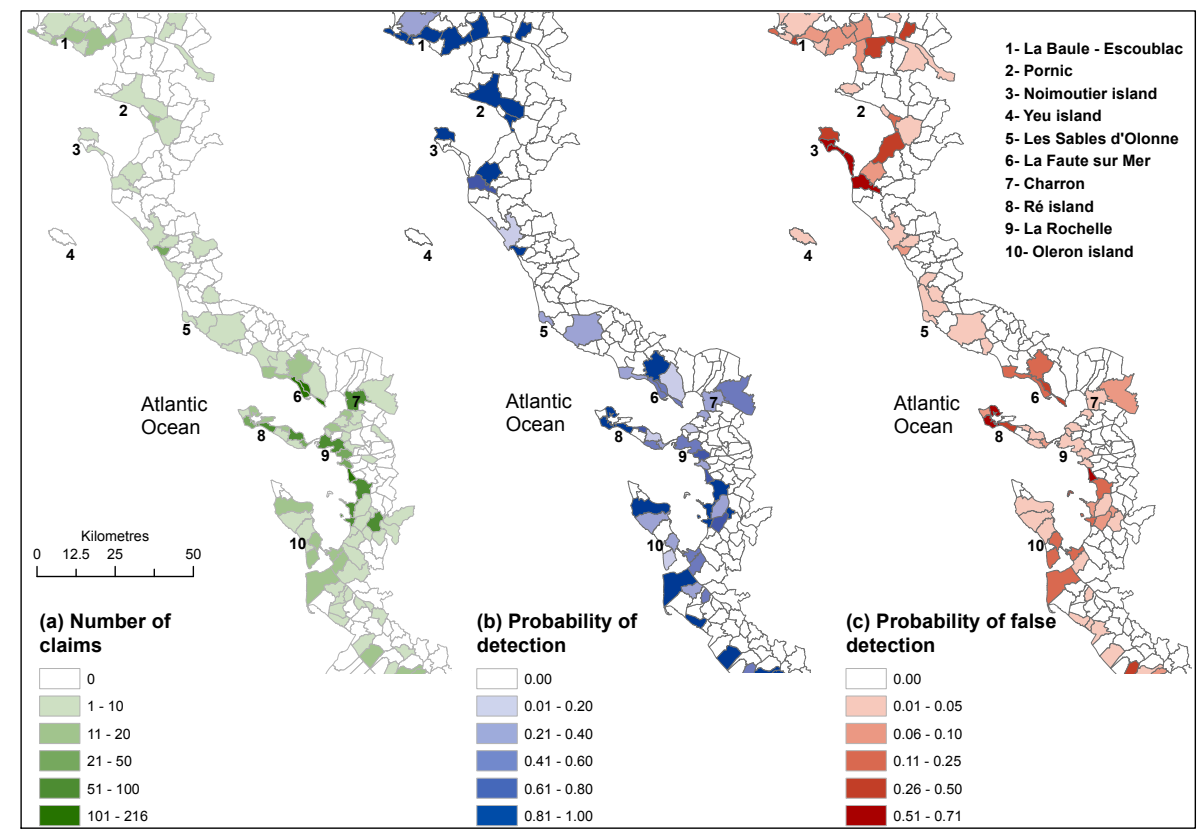

Figure 5. Performances of the system, obtained by comparing claims and insurance policies to the simulated water levels.

(a) Boucholeurs

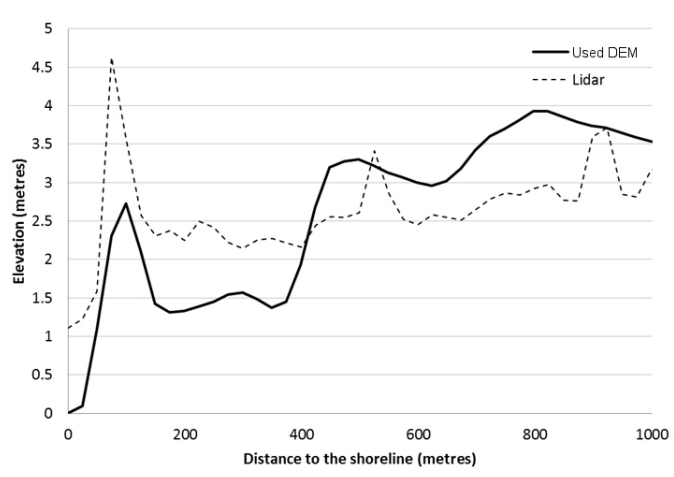

(b) Concarneau

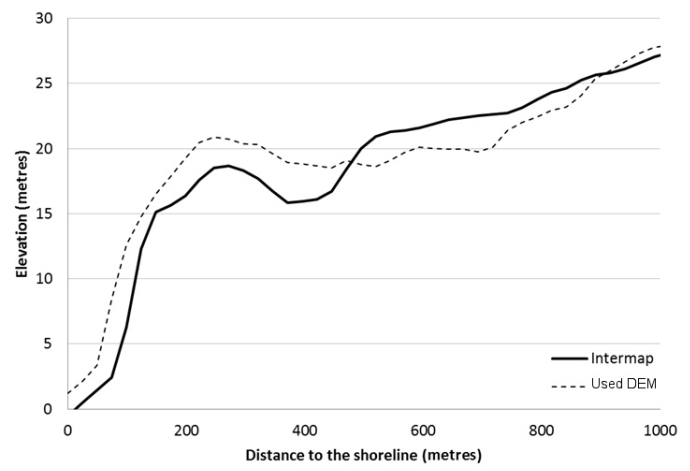

Figure 6. Comparison between the DTM used in this study and a DTM elaborated from lidar observations, interpolated at a $25 \mathrm{~m}$ resolution, for a cross section located in the Boucholeur area (left panel) and near the city of Concarneau (right panel).

cant number of both false alarms and non-detections. Despite these problems, claims give interesting and original information by localizing areas that have been inundated but perhaps not taken into account in the areas otherwise inventoried.

\section{Damage model}

\subsection{Description}

The damage model aims to explain the cost that could be generated according to the magnitude of the phenomena and the vulnerability (policy exposure).

$C_{e, i}=P_{c, i} \cdot T_{d, i} \cdot V_{a, i}$
The aggregation of claim amounts enables the computation of the whole event loss, but also the losses per region, per municipality, or per insurance company. According to Eq. (4), the claim loss estimation of one insurance policy alone is not consistent; the sum of claim probability will be a good estimation of the real number of claims at the event scale, but will not enable identification of the individual claim loss value.

The destruction rate is the relationship between the loss amount and the hazard intensity. Indeed, it is often assumed that the higher the water levels are, the greater the loss will be. Numerous studies have tried to adjust such models on the basis of damage curves describing the loss (cost or destruction rate) as a function of physical parameters such as water levels, velocity, discharge, etc. (Scawthorn et al., 2006; 
Messner et al., 2007; Prettenthaler et al., 2010; Huttenlau et al., 2010; Boettle et al., 2011). In the case of coastal flooding, losses could result from the contact of saltwater with buildings - generating salt and corrosion problems - or from the mechanical action of waves or currents in the most exposed areas (André et al., 2013).

These works often show a very large spread of the losses, especially for high water levels, and it appears that costs also depend on the nature of the risk type. In our study, eight classes of risk have been selected to calibrate the destruction rates: the individual owner (house or apartment), the individual tenant (house or apartment), the house's non-occupant owner, the building's non-occupant owner, the agricultural companies, and other companies. For each of these classes, the destruction rate has been calibrated according to a square root relationship, giving the best results in our case:

$T_{D, i}=a \cdot \sqrt{W D_{i}}$.

For instance, only water levels are taken into account in the loss probability and the damage function. However, some other variables such as flow duration, flow velocity, or the hour at which the phenomenon occurs could be tested in the future but this requires a larger sample field of events.

The claim probability gives the probability of the insured location being damaged according to its water level during the event. Indeed, the data show that a large proportion of goods located in an inundated area are not declared as damaged. This absence of claim could come from the eventual protection of the risk (e.g. issues such as local elevation being more important, or the presence of natural or artificial protections, barriers) or to the low proportion of material damages in comparison to the deductible insurance. The following logistic function is used to calculate the claim probability:

$P_{c, i}=\frac{e^{a+b \cdot W D_{i}+c \cdot S}}{1+e^{a+b \cdot W D_{i}+c \cdot S}} d$,

where WD corresponds to the seawater depth and $a, b, c$, $d$ denote four dimensionless parameters. The variable $S$, qualifying the surge, corresponds to the difference between the maximum water level of the sea and the water level corresponding to a 2-year return period. This variable is calculated for each of the 20 available tide stations and interpolated along the coastline. This interpolation is not designed to predict the storm surge along the coastline accurately but to give an idea of the event magnitude in a given sector and thus to compensate for the lack of precision of the hazard model. This formula provides an estimation of the number of claims by summing the probabilities.

The localization of the policy locus has not always required accuracy to calculate the hazard, especially when the localization is only at communal- or street-level precision. Finally, this model does not enable accurate individual claim statements, but the aggregation of costs at a larger scale produces a representative result.
Table 1. Observed and simulated losses at country scale.

\begin{tabular}{lrrr}
\hline & $\begin{array}{r}\text { Simulated } \\
\text { (million } \\
\text { EUR) }\end{array}$ & $\begin{array}{r}\text { Observed } \\
\text { (million } \\
\text { EUR) }\end{array}$ & Bias \\
\hline Calibration sample & 62.60 & 62.58 & $0.02 \%$ \\
Validation sample & 218.74 & 217.96 & $0.36 \%$ \\
\hline Total & 281.34 & 280.54 & $0.28 \%$ \\
\hline
\end{tabular}

\subsection{Calibration and validation of the damage model}

The calibration of Eqs. (5) and (6) was realized on a small sample of risks for the Xynthia event. The sample chosen was composed of two cedants presenting good-quality data and details of exhaustive claims for the chosen event. Among these policies, only those geo-localized on the roof top were taken into account. This sample represents 71778 policies with 736 claims for the coastal municipalities of the French departments affected by Xynthia.

The validation was realized by comparing the total cost for the 12 major cedants affected by the event - representing about $38 \%$ of the market. These total costs are not the sum of claims, but information directly transmitted by the cedants after the event to overcome the problem of the databases of non-exhaustive claims. Like the other studies in the public domain, a high dispersion is observed in the relationship between destruction rate and water height (Prettenthaler et al., 2010; André et al., 2013).

The results of the calibration exercise, presented in Table 1 , show that the validation allows a good estimation of the total cost for the calibration sample, with a small bias of $0.02 \%$. In the same way, the total losses simulated for the validation sample are near the observed total, with a bias of $0.36 \%$. This bias, caused by risks that are not localized to the address, as well as hydraulic modelling approximations, appears acceptable according to the different uncertainties of the sources.

Finally, the global cost of Xynthia is estimated at EUR 695.6 million which is close to the observed cost which reached EUR 713 million.

\subsection{Sensitivity analysis of the damage model}

The evaluation of the hazard model discussed previously has shown its limitations, in particular the problems of the DTM quality, as well as the limitations of the loss vulnerability database. These limitations are, from our point of view, inherent in the majority of operational systems at such spatial scales. The question is, finally, to know how the loss estimates that constitute the final modelling product are sensitive to these limitations.

According to de Moel et al. (2012), uncertainties in damage estimation are as important as uncertainties in hydraulic 
Table 2. Losses computed at country scale on the basis of several inundation scenarios for the calibration sample.

\begin{tabular}{llllll}
\hline & \multicolumn{5}{c}{$\begin{array}{c}\text { Difference between the scenario and the initial } \\
\text { water levels }(\mathrm{cm})\end{array}$} \\
\cline { 2 - 6 } & -20 & -10 & 0 & +10 & +20 \\
\hline Losses (million EUR) & 484 & 571 & 696 & 769 & 885 \\
Bias & -30.3 & -17.8 & 0 & 10.6 & 27.3 \\
\hline
\end{tabular}

boundary conditions. A test was undertaken to evaluate the sensitivity of the damage model to water levels along the coastline. Thus, the input water levels in the inundation model have been modified throughout the flood duration (i.e. not only on the maximum water level) on the basis of four scenarios: plus or minus $10 \mathrm{~cm}$ and plus or minus $20 \mathrm{~cm}$.

The results of these simulations, presented in Table 2, show that the uncertainties in coastal water level data are prone to generate very different results. Thus, a difference of $10 \mathrm{~cm}$ in water level could vary the total loss by -10.6 to $17.8 \%$. In the same way, a difference of $20 \mathrm{~cm}$ in level induces a variation in the cost of about 27.3 to $30.3 \%$. These important deviations are explained by the increase of the number of risk properties brought into the inundated area. In effect, as illustrated in Fig. 7, a modification of water levels of 10 to $20 \mathrm{~cm}$ could significantly change the extent of the inundation and thus, the number of risk properties affected. These differences specifically concern the flattest areas but could have a great influence on the final insurance cost, especially where urban areas are concerned, because of insured property densities.

Upon examining these results, it can be assumed that the influence of the quality of the DTM is in the same order of magnitude as the seawater levels. If the DTM elevation along the coastline presents an error of a few centimetres, all the adjacent area can be affected in terms of water height and loss estimates. The sensitivity to the seawater levels also illustrates the need to take into account the wave set-up so as to not underestimate the losses. The fact that the wave set-up that could affect the sheltered bays is not taken into account by the model could partially influence the final result. This problem could be overcome by coupling a wave model with the surge model; however it could be time-expensive and thus difficult to put into place in operational conditions.

The system developed has been used to estimate five more event losses: Lothar and Martin (1999), the storms Johanna that affected Brittany in 2008, the storm Xaver that occurred at the end of 2013 in the north of France, and two events that occurred in the Bay of Biscay at the end of January and at the beginning of March 2014 (Christine). For these last three events, the incurred costs are still not available, but according to observations, they should be low even if these three events have severely impacted the coastline, with damage affecting

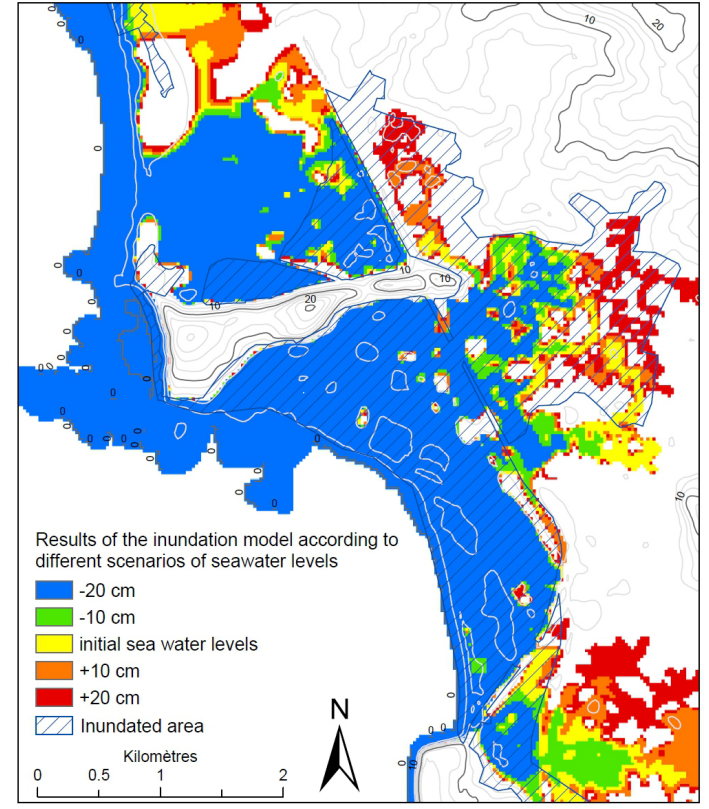

Figure 7. Results of the sensitivity test of the inundation model to the water levels estimated for the sea.

beaches, roads, and dikes. The results of the costs estimated for each event and for the market are presented in Table 3.

Globally, the order of magnitude between the observations and the simulation is respected even if there are some differences. For instance, damages are overestimated by $23 \%$ for Lothar and Martin and by $58.8 \%$ for Johanna. These differences could be explained by the fact that the model was calibrated only for an extreme case and not for less severe events. For Xynthia, the bias between observation and simulated cost is lower than $2.5 \%$, representing a satisfactory performance. The low costs of the three most recent events appear to be consistent with observations which indicate low to moderate damages. Finally, even if the model could still be improved, the estimations already constitute a useful indicator of the magnitude and of the extension of an event.

\section{Conclusions}

The system presented in this article permits the estimation of insurance-related losses due to coastal flooding events in France, especially on the Atlantic coast. The modelling chain, even if limited and still in an early stage of development, is, when applied on a large scale, effective in satisfactorily estimating the magnitude of the resultant financial losses 2 to 3 days after the event occurrence. The estimations are consistent with the few historical events available (especially for Xynthia storm in 2010), and for calibration and validation of the approach.

Coastal flooding modelling at a large scale and within an operational perspective constitutes a difficult exercise that 
Table 3. Comparison between the losses observed and simulated at country scale for five recent events for the French insurance market. The losses of the Xaver event and the two 2014 events are not yet available.

\begin{tabular}{lcclccc}
\hline $\begin{array}{l}\text { Losses } \\
\text { (million } \\
\text { EUR) }\end{array}$ & $\begin{array}{c}\text { Lothar- } \\
\text { Martin } \\
1999\end{array}$ & $\begin{array}{c}\text { Johanna } \\
2008\end{array}$ & $\begin{array}{c}\text { Xynthia } \\
2010\end{array}$ & $\begin{array}{c}\text { Xaver } \\
2013\end{array}$ & $\begin{array}{c}\text { Storm } \\
\text { 30 Jan 2014 }\end{array}$ & $\begin{array}{c}\text { Christine } \\
2014\end{array}$ \\
\hline $\begin{array}{l}\text { Observed } \\
\text { Simulation }\end{array}$ & 45.3 & 16.2 & 713 & - & - & - \\
\hline
\end{tabular}

needs to match the scale of the output results and the accuracy and the complexity of the represented processes. The results emphasize the importance of the quality of topographic information, which constitutes one of the main limiting factors of the system. In order to improve this aspect, the use of other topographic data, such as lidar data (Litto 3D), will be investigated in the future. The results obtained by the sensitivity tests also underline the need for a good estimation of seawater levels and of the wave set-up process, although a future addition of a wave model should improve the system. The validation of the model is also limited by the lack of data due to the limited number of events in France, since the origin of the national NatCat scheme.

Finally, this study illustrates the usefulness of hydrodynamic models for an operational modelling of storm surge. In this situation, the insurance claims data constitute a good indicator of the extent of the inundated areas which could help in the validation of sea surge models. The deterministic model, presented in this article, constitutes the basis of the probabilistic approach under development at CCR. This probabilistic model will be used to evaluate the exposure of the French coast to coastal flooding risk. It is based on the combination of fictive events and hazard scenarios generated by the inundation model. This probabilistic model should allow estimation of the financial exposure of CCR, as reinsurer of the French state, and of insurance companies to storm surge events and losses in the future, but also the potential consequences of sea level rises within climate change scenarios.

Acknowledgements. The authors thank the members of the PREVIMER project for the sharing of their system results and the REFMAR network (http://refmar.shom.fr) for providing the tide gauge data used in this study. They are also grateful to S. J. Rollo-Smith, Z. X. Wang, E. Calando, and N. Orlhac for their suggestions that have improved the quality of this paper.

Edited by: T. Glade

Reviewed by: R. Schwarze and an anonymous referee

\section{References}

André, C., Monfort, D., Bouzit, M., and Vinchon, C.: Contribution of insurance data to cost assessment of coastal flood damage to residential buildings: insights gained from Johanna (2008) and Xynthia (2010) storm events, Nat. Hazards Earth Syst. Sci., 13, 2003-2012, doi:10.5194/nhess-13-2003-2013, 2013.

Ardhuin, F., Rogers, A., Babanin, A., Filipot, J. F., Magne, R., Roland, R., Westhuysen, A. V. D., Queffleulou, P., Lefevre, L., Aouf, L., and Collard, F.: Semi-empirical dissipation source functions for ocean waves: 5 Part I, definition, calibration and validation, J. Phys. Oceanogr., 40, 1917-1941, 2010.

Aronica, G., Bates, P. D., and Horritt, M. S.: Assessing the Uncertainty in Distributed Model Predictions Using Observed Binary Pattern Information within GLUE, Hydrol. Process., 16, 20012016, 2002.

Bates, P. D., Dawson, R. J., Hall, J. W., Horritt, M. S., Nicholls, R. J., Wicks, J., and Mohamed Ahmed Ali Mohamed Hassan: Simplified two-dimensional numerical modelling of coastal flooding and example applications, Coast. Eng., 52, 793-810, 2005.

Bates, P. D., Horritt, M. S., and Fewtrell, T. J.: A simple inertial formulation of the shallow water equations for efficient twodimensional flood inundation modelling, J. Hydrol., 387, 33-45, 2010.

Bertin, X., Bruneau, N., Breilh, J. F., Fortunato, A. B., and Karpytchev, M.: Importance of wave age and resonance in storm surges: the case Xynthia, Bay of Biscay, Ocean Model., 42, 1630, 2012.

Bertin, X., Li, K., Roland, A., Zhang, Y. L. J., Breilh, J. F., and Chaumillon, E.: A modeling-based analysis of the flooding associated with Xynthia, central Bay of Biscay, Coast. Eng., 94, 80-89, 2014.

Bertin, X., Li, K., Roland, A., and Bidlot, J. R.: The contribution of short-waves in storm surges: Two case studies in the Bay of Biscay, Cont. Shelf Res., 96, 1-15, 2015.

Boettle, M., Kropp, J. P., Reiber, L., Roithmeier, O., Rybski, D., and Walther, C.: About the influence of elevation model quality and small-scale damage functions on flood damage estimation, Nat. Hazards Earth Syst. Sci., 11, 3327-3334, doi:10.5194/nhess-113327-2011, 2011.

Bouwer, L. M., Bubeck, P., Wagtendonk, A. J., and Aerts, J. C. J. H.: Inundation scenarios for flood damage evaluation in polder areas, Nat. Hazards Earth Syst. Sci., 9, 1995-2007, doi:10.5194/nhess9-1995-2009, 2009.

Breilh, J. F., Chaumillon, E., Bertin, X., and Gravelle, M.: Assessment of static flood modeling techniques: application to contrasting marshes flooded during Xynthia (western France), Nat. 
Hazards Earth Syst. Sci., 13, 1595-1612, doi:10.5194/nhess-131595-2013, 2013.

Bunya, S., Dietrich, J. C., Westerink, J. J., Ebersole, B. A., Smith, J. M., Atkinson, J. H., Jensen, R., Resio, D. T., Luettich, R. A., Dawson, C., Cardone, V. J., Cox, A. T., Powell, M. D., Westerink, H. J., and Roberts, H. J.: A High-Resolution Coupled Riverine Flow, Tide, Wind, Wind Wave, and Storm Surge Model for Southern Louisiana and Mississippi. Part I: Model Development and Validation, Mon. Weather Rev., 138, 345-377, doi:10.1175/2009MWR2906.1, 2010.

Courtier, P., Thepaut, J., and Hollingsworth, A.: A strategy for operational implementation of 4D-VAR, using an incremental approach, Q. J. Roy. Meteorol. Soc., 120, 1367-1387, 1994.

Czajkowski, J., Kunreuther, H., and Michel-Kerjan, E.: Quantifying Riverine and Storm-Surge Flood Risk by SingleFamily Residence: Application to Texas: Quantifying Catastrophic Flood Risk in Texas, Risk Analysis, 33, 2092-2110, doi:10.1111/risa.12068, 2013.

de Moel, H., Asselman, N. E. M., and Aerts, J. C. J. H.: Uncertainty and sensitivity analysis of coastal flood damage estimates in the west of the Netherlands, Nat. Hazards Earth Syst. Sci., 12, 10451058, doi:10.5194/nhess-12-1045-2012, 2012.

Ferrarin, C., Roland, A., Bajo, M., Umgiesser, G., Cucco, A., Davolio, S., Buzzi, A., Malguzzi, P., and Drofa, O.: Tide-surge-wave modelling and forecasting in the Mediterranean Sea with focus on the Italian coast, Ocean Model., 61, 38-48, 2013.

FFSA - Fédération Française des Sociétés d'Assurance - and GEMA - Groupement des Entreprises Mutuelles d'Assurance: La tempête Xynthia du 28 février 2010 - Bilan chiffre au 31 décembre 2010, 19 pp., available at: http://www.ffsa.fr/sites/ upload/docs/application/pdf/2011-06/bilanxynthia28022011.pdf (last access: 14 January 2016), 2011.

Gaslikova, L., Schwerzmann, A., Raible, C. C., and Stocker, T. F.: Future storm surge impacts on insurable losses for the North Sea region, Nat. Hazards Earth Syst. Sci., 11, 1205-1216, doi:10.5194/nhess-11-1205-2011, 2011.

Genovese, E., Hallegatte, S., and Dumas, P.: Damage Assessment from Storm Surge to Coastal Cities: Lessons from the Miami Area, in: Advancing Geoinformation Science for a Changing World, edited by: Geertman, S., Reinhardt, W., and Toppen, F., Springer, Berlin, Heidelberg, 21-43, 2011.

Holman, R. A. and Sallenger, A. H.: Setup and Swash on a Natural Beach, J. Geophys. Res., 90, 945-953, 1985.

Horritt, M. S. and Bates, P. D.: Predicting floodplain inundation: raster-based modeling versus the finite-element approach, Hydrol. Process., 15, 825-842, 2001.

Hunter, N. M., Horritt, M. S., Bates, P. D., Wilson, M. D., and Werner, M. G. F.: An adaptive time step solution for raster-based storage cell modelling of floodplain inundation, Adv. Water Resour., 28, 975-991, 2005.

Huttenlau, M., Stötter, J., and Stiefelmeyer, H.: Risk-based damage potential and loss estimation of extreme flooding scenarios in the Austrian Federal Province of Tyrol, Nat. Hazards Earth Syst. Sci., 10, 2451-2473, doi:10.5194/nhess-10-2451-2010, 2010.

Idier, D., Dumas, F., and Muller, H.: Tide-surge interaction in the English Channel, Nat. Hazards Earth Syst. Sci., 12, 3709-3718, doi:10.5194/nhess-12-3709-2012, 2012.

Jongman, B., Kreibich, H., Apel, H., Barredo, J. I., Bates, P. D., Feyen, L., Gericke, A., Neal, J., Aerts, J. C. J. H., and Ward, P.
J.: Comparative flood damage model assessment: towards a European approach, Nat. Hazards Earth Syst. Sci., 12, 3733-3752, doi:10.5194/nhess-12-3733-2012, 2012.

Kim, S. Y., Yasuda, T., and Mase, H.: Numerical analysis of effects of tidal variations on storm surges and waves, Appl. Ocean Res., 30, 311-322, doi:10.1016/j.apor.2009.02.003, 2008.

Lazure, P. and Dumas, F.: An external-internal mode coupling for a 3D hydrodynamical model for applications at regional scale (MARS), Adv. Water Resour., 31, 233-250, 2008.

Lecacheux, S., Pedreros, R., Le Cozannet, G., Thiébot, J., De La Torre, Y., and Bulteau, T.: A method to characterize the different extreme waves for islands exposed to various wave regimes: a case study devoted to Reunion Island, Nat. Hazards Earth Syst. Sci., 12, 2425-2437, doi:10.5194/nhess-12-2425-2012, 2012.

Le Roy, S., Pedreros, R., André, C., Paris, F., Lecacheux, S., Marche, F., and Vinchon, C.: Coastal flooding of urban areas by overtopping: dynamic modelling application to the Johanna storm (2008) in Gâvres (France), Nat. Hazards Earth Syst. Sci., 15, 2497-2510, doi:10.5194/nhess-15-2497-2015, 2015.

Lopes, C., Azevedo, A., and Dias, J.: Flooding assessment under sea level rise scenarios: Ria de Aveiro case study, J. Coast. Res., 65, 766-771, 2013.

Lumbroso, D. M. and Vinet, F.: A comparison of the causes, effects and aftermaths of the coastal flooding of England in 1953 and France in 2010, Nat. Hazards Earth Syst. Sci., 11, 2321-2333, doi:10.5194/nhess-11-2321-2011, 2011.

Lyard, F., Lefevre, F., Letellier, T., and Francis, O.: Modelling the global ocean tides: modern insights from FES2004, Ocean Dynam., 56, 394-415, doi:10.1007/s10236-006-0086-x, 2006.

Messner, F., Penning-Rowsell, E., Green, C., Meyer, V., Tunstall, S., and van der Veen, A.: Evaluating flood damages: guidance and recommendations on principles and methods, Tech. Rep. T09-06-01, Floodsite, available at: http://www.floodsite.net/html/partner_area/project_docs/t09_ 06_01_flood_damage_guidelines_d9_1_v2_2_p44.pdf (last access: 14 January 2016), 2007.

Meyer, V. and Messner, F.: National flood damage evaluation methods: A review of applied methods in England, the Netherlands, the Czech Republik and Germany, UFZ Discussion Papers No. 21/2005, https://www.ufz.de/export/data/1/26214_ dp212005.pdf (last access: 14 January 2016), 2005.

Meyer, V., Becker, N., Markantonis, V., Schwarze, R., van den Bergh, J. C. J. M., Bouwer, L. M., Bubeck, P., Ciavola, P., Genovese, E., Green, C., Hallegatte, S., Kreibich, H., Lequeux, Q., Logar, I., Papyrakis, E., Pfurtscheller, C., Poussin, J., Przyluski, V., Thieken, A. H., and Viavattene, C.: Review article: Assessing the costs of natural hazards - state of the art and knowledge gaps, Nat. Hazards Earth Syst. Sci., 13, 1351-1373, doi:10.5194/nhess-13-1351-2013, 2013.

Moncoulon, D., Labat, D., Ardon, J., Leblois, E., Onfroy, T., Poulard, C., Aji, S., Rémy, A., and Quantin, A.: Analysis of the French insurance market exposure to floods: a stochastic model combining river overflow and surface runoff, Nat. Hazards Earth Syst. Sci., 14, 2469-2485, doi:10.5194/nhess-14-24692014, 2014.

Muller, H., Pineau-Guillou, L., Idier, D., and Ardhuin, F.: Atmospheric storm surge modeling methodology along the French (Atlantic and English Channel) coast, Ocean Dynam., 64, 16711692, 2014. 
Pistrika, A. K. and Jonkman, S. N.: Damage to residential buildings due to flooding of New Orleans after hurricane Katrina, Nat. Hazards, 54, 413-434, 2009.

Prettenthaler, F., Amrusch, P., and Habsburg-Lothringen, C.: Estimation of an absolute flood damage curve based on an Austrian case study under a dam breach scenario, Nat. Hazards Earth Syst. Sci., 10, 881-894, doi:10.5194/nhess-10-881-2010, 2010.

Rexer, M. and Hirt, C.: Comparison of Free High Resolution Digital Elevation Data Sets (ASTER GDEM2, SRTM v2.1/v4.1) and Validation against Accurate Heights from the Australian National Gravity Database. Australian, J. Earth Sci., 61, 213-226, 2014.

Scawthorn, C., Flores, P., Blais, N., Seligson, H., Tate, E., Chang, S., Mifflin, E., Thomas, W., Murphy, J., Jones, C., and Lawrence, M.: HAZUS-MH Flood Loss Estimation Methodology. II. Damage and Loss Assessment, Nat. Hazards Rev., 7, 72-81, 2006.

Seity, Y., Brousseau, P., Malardel, S., Hello, G., Bénard, P., Bouttier, F., Lac, C., and Masson, V.: The AROME-France convective scale operational model, Mon. Weather Rev.,139, 976-991, 2011.

SHOM: Références Altimétriques Maritimes, Tech. rep., SHOM, Brest, France, 2012.
Simon, G., Dumas, F., and Duhaut, T.: Spectral analysis of mean flow and turbulence forced by waves in a horizontally homogeneous zone of the Iroise sea, Ocean Dynam., 61, 1887-1903, 2011.

Sousounis, P. and Kafali, C.: Insured loss estimation from wind and storm surge for a re-occurrence of typhoon Vera, Presented at the 29th Conference on Hurricanes and Tropical Meteorology, Tucson, p. 8, 2010.

Stockdon, H. F., Holman, R. A., Howd, P. A., and Sallenger, A. H.: Empirical parameterization of setup, swash, and runup, Coast. Eng., 53, 573-588, doi:10.1016/j.coastaleng.2005.12.005, 2006.

Townend, I. and Pethick, J.: Estuarine flooding and managed retreat, Philos. T. Roy. Soc. A, 360, 1477-1495, 2002.

Waeles, B., Bertin, X., Breilh, J.-F., Li, K., and Le Mauff Dorn, B.: Limitation of high water levels in bays and estuaries during storm flood events, in: SimHydro 2014, Presented at the Modelling of rapid transitory flows, Sophia Antipolis, p. 9, 2014.

Wang, H., Loftis, J., Liu, Z., Forrest, D., and Zhang, J.: The Storm Surge and Sub-Grid Inundation Modeling in New York City during Hurricane Sandy, J. Mar. Sci. Eng., 2, 226-246, 2014.

Wilks, D. S.: Statistical methods in the atmospheric sciences, Academic Press, Oxford, Waltham, MA, 2011. 